\title{
SCHOOL PLANT MAINTENANCE AND STUDENTS ACADEMIC PERFORMANCE IN PUBLIC SECONDARY SCHOOLS IN BAYELSA STATE
}

\section{Moses Ebimuna}

Department of Education Management, Faculty of Education, Ignatius Ajuru University of Education, Rumuolumeni, Port Harcourt, Rivers State

Email: mosesebimuna@gmail.com

Cite this article:

Moses Ebimuna (2021),

School Plant Maintenance and Students Academic Performance in Public Secondary Schools in Bayelsa State. British Journal of Education, Learning and Development Psychology 4(1) DOI: 10.52589/BJELDPCBOZ7YPY.

\section{Manuscript History}

Received: 28 April 2021

Accepted: 20 May 2021

Published: 11 June 2021

Copyright $\odot 2020$ The Author(s). This is an Open Access article distributed under the terms of Creative Commons AttributionNonCommercial-NoDerivatives 4.0 International (CC BY-NC-ND 4.0 ), which permits anyone to share, use, reproduce and redistribute in any medium, provided the original author and source are credited.

\begin{abstract}
This study investigates school plant maintenance and students' academic performance in public secondary schools in Bayelsa state. The correlational survey research design was adopted for the study. The population of this study was eighty-two thousand, five hundred and eighty-two (82,582) students of the 191 public secondary schools in the eight (8) Local government areas of Bayelsa state. A sample of 300 students was drawn from 12 schools, having a total population of 5120 students was sampled for this study. The instrument that was used for data collection in this study was a self-structured 4-point Likert Scale Modified questionnaire titled: School Plant Maintenance and Students Academic Performance in Public Secondary Schools Questionnaire. (SPMSAPPSSQ). A test-retest method was used to ascertain the reliability of the instrument. The two sets of scores were computed using Pearson product moment correlation to determine the reliability index value 0.72 while the hypothesis is at 0.05 level of significance. The findings of this study revealed that maintenance of a blackboard helps the students to see clearly, thereby enhancing their academic performance; the maintenance of ICT building enables students to take part in ICT classes effectively and that steady maintenance of the library makes it possible for reliable and current books to be available for students to study widely. The study concludes by establishing the relationship between school plants maintenance and students' academic performances in public senior secondary schools in Bayelsa State and recommended that government and schools board should often investigate the level of fitness and stability of school plants and embark on renovation and replacement of dilapidated and worn-out facilities in order to promote students' academic performances.
\end{abstract}

KEYWORD: School, Plant Maintenance, Students, Academic Performance, Public Secondary Schools. 


\section{INTRODUCTION}

The school is a formal organization and veritable machinery for the development of a country. It is made up of school administrators or heads of school, school teachers and students. They all form a group of people in constant interaction on a daily basis within the school environment geared towards transmission of societal values. In the light of these values, education today must prepare the child to function effectively as an adult in the 21 st century. However, Nigerian schools are the least ready to adapt to the onslaught of new information and practices accumulating on a daily basis due to the challenges ranging from poor school plant maintenance, lack of funds for infrastructural development and a host of others. This is evident in the suggestion that teachers are handicapped by inadequate facilities which made it difficult for the teachers to prepare students for the new development.

School plant is one of the major aspects of school administration and refers to all the material provisions in a school environment while school plant maintenance has to do with all the necessary care given to all the facilities used in the school. Amanchukwu and Ololube (2015), describe school plant as the school site and all the essential structure permanent and semipermanent such as machines and laboratory equipment and chalkboard needed for effective teaching and learning. School plant is the space interpretation of the school curriculum. In this case, the curriculum will be impossible to implement without the physical facilities required for teaching and learning which are neither available nor inadequately provided and maintained. The general attitude of school administrators towards the maintenance of the school plant in turn determines to some extent, the efficiency in the use and effectiveness of the school plant in supporting the academic programme and satisfying the needs of the users including the members of the community.

It is believed that a well-maintained school plan will gear up expected outcomes of education that will facilitate effective teaching and learning processes and academic performance of the students (Adesina, 2011). Emphasizing the importance of school plant maintenance on students' academic performance, Oluchukwu (2000) asserted that school plant planning and maintenance like school buildings, classrooms, library and laboratory, school environment is an essential aspect of educational planning. If school facilities are not well maintained, adequate utilization becomes impossible entailing that effective teaching and learning may not take place.

School plants will enhance better school programmes and the community needs by providing a place for psychological and physical safety for students and teachers and enhancing the good quality and quantity of instruction. Academic performance is the outcome of education. It is the extent to which a student, teacher or institution has attained a level of educational goals. Thus, students' academic performance is characterized by performance on tests associated with subject work and the performance of students on other types of examinations which of course is guaranteed through effective provision and maintenance of school plants which involves school buildings, libraries and laboratories, ICT facilities, classrooms, etc. Similarly, Ajayi (2007) maintained that high levels of students' learning outcomes may not be guaranteed where school plant maintenance and planning are not properly undertaken and the plant components themselves are structurally defective, not properly ventilated and not spacious enough for use.

The fundamental purpose of teaching and learning is to bring about positive change in behaviour through critical thinking. This process does not take place in a vacuum but in an 
environment well equipped and set aside to facilitate learning. Managing the instructional materials helps in promoting effective teaching and learning for the overall development of the entire school system. Since education seeks to develop the minds and character of future citizens; their abilities, skills and potentials must be nurtured to meet the needs for contemporary society. To do this, school plants have to be supplied in adequate quantity and quality and maintained effectively through thorough supervision.

\section{Statement of the Problem}

Nigerian secondary schools face the combined challenges of poor school plant planning, deteriorating conditions, out-of-date design and capacity utilization pressures due to the continuous neglect by government and schools' administrators. These have posed a threat to the maintenance of school plants in most public schools in Nigeria. Particularly, public secondary schools in Bayelsa State are in very deplorable conditions, causing students to suffer unwarranted inconveniences before, during and after school hours. The whole idea for the setting up of schools would be forfeited if public secondary school plants are not maintained adequately, hence this in return may have a negative effect on the performance of students. A visit to some schools in Bayelsa state reveals that most school compounds are bushy with dilapidated buildings and leaking roofs, broken chairs and desks, rough floors and windows without louvers. In some of the schools, the buildings are another source of worry. The buildings are dirty, very dilapidated and often in shambles which make the school environment dull and unattractive; this is tantamount to creating a very hostile study environment.

Several researchers have investigated factors such as school climate, instructional materials, school gates, physical facilities, and infrastructure as components that affect students' learning outcomes, but not many have bothered much on the impact of school plant maintenance on students' academic performance. It seems that public secondary schools in Bayelsa state still lack good and reliable maintenance culture.

In the light of the foregoing, the researcher is bothered about the school infrastructures, lack of lightning, blown off roofs which indicate absence of or little maintenance, deteriorated laboratories that are harmful and unhealthy conveniences such as toilets, which could cause sickness to both teachers and students, poor state of library facilities which reduces the motivation of students in cultivating a good reading culture and also most of the school compounds have turned into wild forest thereby, denying the students ample space for recreational/extracurricular activities. These and many more have left the schools in a very sorry state. All these ugly situations could be attributed to inadequate and poor maintenance culture which may have affected students' academic performance.

Therefore, it is against this crux that this study intends to investigate school plant maintenance and students' academic performance in public secondary schools in Bayelsa State.

\section{Aim and Objectives of the Study}

The overall aim of this study was to investigate school plant maintenance and students' academic performance in public secondary schools in Bayelsa state. Specifically, the study sought to:

- Determine the extent to which maintenance of school furniture influences students' academic performance in public secondary schools in Bayelsa state. 
- Ascertain the extent to which maintenance of school building influences students' academic performance in public secondary schools in Bayelsa state.

- Investigate the extent to which maintenance of school library facilities influences students' academic performance in public secondary schools in Bayelsa state.

\section{Research Questions}

The study was guided by the following research questions:

- To what extent does maintenance of school furniture influence students' academic performance in public secondary schools in Bayelsa state?

- To what extent does maintenance of school building influence students' academic performance in public secondary school in Bayelsa state?

- To what extent does maintenance of school library facilities influence students' academic performance in public secondary schools in Bayelsa state?

\section{Hypotheses}

In order to guide this study, the following hypotheses were raised and tested at 0.05 level of significance:

HO1: There is no significant relationship between maintenance of school furniture and students 'academic performance in public secondary schools in Bayelsa state.

HO2: There is no significant relationship between maintenance of school building and students' academic performance in public secondary schools in Bayelsa state.

HO3: There is no significant relationship between maintenance of school library facilities and students' academic performance in public secondary schools in Bayelsa state.

\section{THEORETICAL FRAMEWORK}

\section{Theory of Adequacy, Economy, Efficiency and Utilization of Educational Resources}

This study anchored on the theory of adequacy, economy, efficiency and utilization of educational resources propounded by Castaldi 1987 as cited in Dodo (2018). The theory states that adequacy of school facilities is measured on the extent it satisfies both the qualitative and quantitative requirement of a school programme. With this theory Castaldi asserts that the space provided must be enough to accommodate the planned educational programme. He also asserts that the basic condition for achieving educational objectives is adequacy utilization and materials and emphasizes that the reason for establishing learning institutions is to achieve quality delivery of education if both physical and human resources are provided and properly maintained then the resources would fulfil the designed purpose. Therefore, in our educational system, it is good that the space provided should be up to the minimum size needed for programmes that have been designed for. Owhondah (2007) states that the planned educational programme must be achieved at a minimum cost. The theory of economy states that economy is the achievement of maximum educational and utilization values per naira expended and not 
the acquisition of school facilities for a given enrollment at the lowest cost. However, the achievement of the educational programme at a minimum cost should not negatively affect the educational efficiency of the school and should not cause high-cost maintenance based on these, the school plants will be maximally maintained and utilized resulting in a longer life span.

\section{CONCEPTUAL CLARIFICATION}

\section{School Plant}

School plant is one of the major aspects of school administration and refers to all the material provisions in a school environment. Njoku (2004) describes school plants as educational facilities that are tangible such as buildings, land equipment, machineries, furniture, fixtures and fittings which are put into use and capable of providing excellent educational services. Yusuf (2003) defined school plants as space interpretation of school curriculum. This means it will be impossible for the curriculum to be implemented if the physical facilities required for teaching and learning are not available. It also includes the site, the building and the equipment. It includes permanent and semi-permanent structure as well as items such as machines, laboratory equipment, the blackboard/chalkboard, the learner and teacher tools.

School plants also refer to as the entire physical infrastructural facilities provided in the school for the purpose of educating the child which include the school site and all the structures that have been put in place to aid effective teaching and learning in the school system. Moreover, school plant refers to all non-consumable and durable physical and infrastructural facilities available in the school for teachers' and students use in order to make teaching and learning effective and thus ensure the achievement of predetermined aims and objectives of education. Hence, the school plant includes the space within the school premises which houses the basic systems and structures.

Asiabaka (2008) defines school plant as an integral element in teaching and learning environment because of its direct and indirect roles. Olaniyan and Anthony (2013) asserted that school plants are facilities which physically and spatially enable teaching and learning and by extension help in producing desirable results as evidenced by good academic performance of products of an education. School facilities as school plants' permanent structures which include buildings, libraries, chairs, machines, technical workshops, playground and other nonhuman resources that aid the actualization of teaching and learning objectives (Asiyai, 2012).

\section{Importance of School Plant}

Many researchers have shown the obvious relationship between school plant and curriculum which in turn affects effective teaching and learning. The impacts of the physical environment, in which teaching and learning takes place, is very important. They include:

- School plant helps improve students' academic performance in achievement test like (WAEC, NECO, JAMB, etc.)

- School plant improves attendance of students and reduces dropout rate.

- School plant improves students' attitude toward learning. 
- School plant increase teachers' intention rate.

- It boosts teaching effectiveness, and etc. generally, school plant is very essential for academic achievement and it promotes positive outcomes in the teaching and learning process. The school plant is the pillar and support of all teaching activities.

\section{Approaches to School Plant Maintenance}

According to Ibara (2018); Akomolafe, and Adesua (2016), there are three (3) approaches to school plant maintenance administrations.

- The Local System Maintenance Programme: This involves education authority operating its own system of maintenance; it also prevents delay associated with the bidding and negotiating processes and saves some overhead costs which are changed by those performing the maintenance function. It reduces time delay associated with contracts and it makes it possible for administrators to make more efficient use of personnel, in terms of scheduling peak-load and peak -time operations.

- The Contracted Maintenance Programme: This approach entails contracting the maintenance work when due to consultants instead of employing staff.

- Combination of both: This means using the first and second approach for maintenance programs within the school environment.

\section{School Plant Maintenance Techniques}

There are various types of maintenance techniques widely undertaken in industry which are easily applicable in the maintenance of the school plant. Okonkwo (2018) identified a number of maintenance techniques which can be specified either separately or in combination for each item of plant, they are:

- Routine maintenance: This type of maintenance technique helps to provide a safe working environment and covers such areas as general clean ups. Inspection and minor servicing of instruments of belts, chains, etc., as well as inspection and cleaning of lighting fixtures and stocking of frequently needed parts.

- Preventive maintenance: This type of maintenance technique has to do with a scheduled inspection and services procedure which is designed to prevent equipment breakdown and malfunctions through early detection and remedy of the cause. Such as periodic inspection and replacing parts periodically and recording inspection reports of school plants.

- $\quad$ Fixed-time maintenance: This type of maintenance technique is dependent on time, and is only effective in the following circumstances: when failure is clearly time dependent; when the component is expected to wear out within the time of the unit.

- Condition based maintenance: This has to do with the actual current condition of the plant and equipment that determines the form and frequency. It is corrective in nature as a result of monitoring of school facilities in the school. 
- Opportunity maintenance: This refers to maintenance actions carried out during fixed time or condition-based repair, but specifically concerns with items other than those originally the cause of the repair.

- Corrective maintenance: It is concerned with the detection, location and repair of faults as they occur. It also referred to servicemen as breakdown maintenance, repair maintenance, replace-as they-fail maintenance. It includes such improvements as minor changes in design, and substitutions of more suitable components or improvement of materials of construction to eliminate problems.

- Predictive Maintenance: Is a new concept and practice used in measuring, sensing and monitoring devices to determine significant changes in product and recognizing that a change in the physical condition of equipment is the root cause of breakdown. It is possible with this technique to identify conditions that require correction before a major problem develops.

- Planned maintenance: This is where instructions are more detected than in routine maintenance. The frequency of services given to all equipment are established, data of annual, quarterly services are set.

- Overhaul maintenance: This has to do with following planned maintenance procedure in order to complete disassembly of machinery or equipment, location of the faults, replacement of major and other parts, which depreciated in function.

- Periodic maintenance: Maintenance work that is usually done on regular intervals of more. Most often this type of maintenance work is done on contract basis at predetermined times. It is also associated with the servicing of office, laboratory, and other equipment in the school periodically.

- Regular maintenance: This type of maintenance is given to special equipment on the school periodic basis.

- Shut-down maintenance: This can also be called turnaround maintenance. Maintenance activity which will be done when the students are on vacation to avoid accident or unnecessary disturbance. When a school plant or a certain part of it is shut down for the specific purpose of carrying out maintenance work.

\section{Academic Performance}

The performance of students in public secondary schools in their area of studies has been an issue with some schools producing very few graduates with a grade of $\mathrm{C}+$ which is a minimum requirement for any tertiary education in Nigeria. According to Wikipedia (2013), academic performance is the outcome of education. It is the extent to which a student, teacher or institution has attained a level of educational goals. Thus, students' academic performance is characterized by performance on tests associated with subject work and the performance of students on other types of examinations (Kyoshaba, 2009). Similarly, Wikipedia (2019) noted that academic performance is commonly measured through examination or continuous assessment but no general agreement on how it is best evaluated in terms of procedural knowledge such as skills or declarative knowledge such as facts. Meanwhile, various studies have been carried out on the factors that affect students' academic performance in schools. 
Some of the factors identified and reported to have affected the academic performance of students from one way the other will be are:

- $\quad$ self-discipline or student effort: this has to do with commitment in school,

- $\quad$ socio-economic status of the students it has to do with parental financial background of the students;

- age: the level of maturity and the kind of age required during the period;

- number of hours of study per day;

- Tuition trends and student's area of residence: which has to do with the (rural or urban);

- Health status of the students also go along way of determining the level of academic performance of students

- Physical challenge or exceptional causes could be major factors as well and so on.

All these are either positively or negatively contributing to the level of academic achievement of students.

\section{School Furniture Maintenance and Academic Performance of Students}

The need for furniture maintenance arises due to a member of factors among which include daily routine use, aging over use, changing course content which affects the use of furniture, extreme climate conditions which causes deterioration and lack of funding. Xaba (2012) is of the view that maintenance of school furniture is unsystematic and not logistic. However, Ekpoh (2018) is of the view that instituting school involves making plant maintenance an integral part of school administration. Furniture maintenance has to do with repairs, changes and general upkeep of the furniture found in schools.

\section{Maintenance of School Building and Student Academic Performance}

School building consists of classrooms, offices, convenience sporting facilities, security, laboratories halls and workshops. Bloom in Nweneka (2016) opines that a well functional school building with a wide array of teaching and learning aids provide positively related to quality assurance in academic performance. The quality of education received by the students bears direct relevance to the availability or lack of physical facilities and the overall environment in which learning takes place. Availability of adequate and sufficient school plant is thus expected to positively reflect the academic performance of students (Hamdallah, 2013)

Proper maintenance culture is an alternative when compared to the financial implication and cost when available school building facilities are left to deteriorate. The school manager must engage in suitable maintenance practice to lengthen the life span or durability of school buildings. This will in turn safe lives, cost and also attract parents to school. Maintenance must satisfy some objectives which include prevention of school building deterioration (which include furniture as well) and ensure other contingencies such as broken windows, leaking roofs, and doors. There is actually a belief that the outward appearance of schools affects the learning and academic performance of students and teachers' efficiency. 


\section{Maintenance of School Library and Students' Academic Performance}

The information resources in our school are very vast and fast growing. It is important for both teachers and students to be aware of the formal processing strength and use of the library resources. Teaching and learning mostly takes place in the classroom. However, a reasonable amount of the materials needed for effective teaching and learning are found in the library. The school library provides basic ancillary services that should be provided by any didactive institution (Agabi \& Okrie, 2002). Books in the library are made appropriate for the age and level of the learner. The needs of the students and teachers must be captured when setting up a library. The library is made of books and non-book materials such as records, files, slides and artifacts. The library plays a major role in the enhancement of learning and teaching activities which take place in the classroom.

\section{EMPIRICAL STUDY}

Wordu and Nlerenchi (2019) conducted a work on school plant provision and academic performance of secondary school students in Tai and Eleme local government areas, River State. A survey design was adopted. The result of the analyses showed that a significant relationship exists between school plant provision and academic performance of students in the secondary schools. The study recommended that school buildings should be designed with adequate space, ventilation, lighting, humidity and temperature. Instructional materials, library facilities and science laboratories should be adequately provided, the study further recommended that school administrators should take the challenge of providing adequate school facilities to ensure and sustain higher academic performance.

Akomolafe and Adesua (2016) opine that the study examined the relevance of physical plants in enhancing the level of motivation and the academic performance of senior secondary school students in south west Nigeria. The study adopted ex-post facto design; the population consists of all senior secondary students in south west Nigeria. The sample size for the study was one thousand and fifty senior secondary school students from three states out of the six students in the south west geo-political zone. The researcher made use of a questionnaire and an inventory to collect data. The result showed that there was a significant relationship between physical plant and students' level of motivation and academic performance.

\section{Constraints to School Plant Maintenance Culture}

Some of the factors that militate against school plant maintenance culture include:

- Financial Constraint: Finance is a crucial factor when setting up any project in the school and architectural design of the school plant. Sometimes substandard materials are used for school building and facilities.

- Economic Factors: When the economy is not strong it affects every aspect of life. A country's economy melts down and also affects setting up projects in the school, low school environment, poor founding of school plant or facilities has contributed to low quality of school materials or facilities.

- Poor maintenance culture: Wrong attitude towards handling school facilities makes some schools suffer from gross dilapidation of facilities. 
- Vandalization by Students: The presence of vandalism at school by the students cost money and makes school facilities less attractive and even unsuitable. Thus, the school should provide orientation to students and other personnel on the importance of watching and caring for school property.

- Unclear Roles of School Heads: Heads of secondary schools have complained that their roles regarding maintenance of a school plant have remained unclear. Thus, when vital equipment breaks down close to examination period the principal or school head would be in a dilemma on how to fix it quickly. in such emergency situations. Heads of school often spend their money in anticipation of refunds which handily comes. Therefore, school heads often remain helpless and watch school facilities waste when little funds could have restored their functionality.

- Lack of in-House Training on Facility Maintenance: Teachers, students and custodial staff are the major beneficiaries of a school plant which are not trained on the handling and minor maintenance of school facilities.

\section{Methods}

The correlational survey research design was adopted for the study. The population of this study was eighty-two thousand, five hundred and eighty-two $(82,582)$ students of the 191 public secondary schools in the eight (8) Local government areas of Bayelsa state. A sample of 300 students was drawn from 12 schools, having a total population of 5120 students was sampled for this study. To arrive at this, a simple random sampling technique will be used to select 3 local government areas from where 4 schools each will be selected to realize the 12 schools selected. The 3 local government areas selected represent $37 \%$ of the total population of local government areas in Bayelsa state.

The instrument that was used for data collection in this study was a self-structured 4-point Likert Scale Modified questionnaire titled: School Plant Maintenance and Students Academic Performance in Public Secondary Schools Questionnaire. (SPMSAPPSSQ).

To ensure face and content validities of the instrument, the questionnaire was presented to the supervisor, two other experts in the department of educational management and three experts in measurement and evaluation for examination and scrutiny. A test-retest method was used to ascertain the reliability of the instrument. The two sets of scores were computed using Pearson product moment correlation to determine the reliability index value 0.72 while the hypothesis is at 0.05 level of significance. 


\section{RESULTS AND DISCUSSION}

Research Question One: To what extent does maintenance of school furniture affect students' academic performance in public secondary schools in Bayelsa state?

Table 1: Mean ratings and standard deviation of the respondents on the extent maintenance of school furniture influences students' academic performance in public secondary schools in Bayelsa state.

\begin{tabular}{|c|c|c|c|c|}
\hline $\mathrm{S} / \mathrm{N}$ & Description of Items & $\mathbf{X}$ & S. D & Decision \\
\hline 1 & $\begin{array}{l}\text { The maintenance of blackboard helps the students to } \\
\text { see clearly, thereby enhancing their academic } \\
\text { performance. }\end{array}$ & 2.15 & 1.16 & Agreed \\
\hline 2 & $\begin{array}{l}\text { The maintenance of wooden chairs helps the students } \\
\text { to sit } \\
\text { orderly, thereby motivating them to learn effectively. }\end{array}$ & 2.71 & 1.48 & Agreed \\
\hline \multirow[t]{2}{*}{3} & $\begin{array}{l}\text { The maintenance of shelves helps in keeping of books } \\
\text { properly to avoid spoilage which makes the books } \\
\text { handy for students to } \\
\text { read, thereby facilitating students learning }\end{array}$ & 2.66 & 1.15 & Disagreed \\
\hline & outcome. & & & \\
\hline 1 & $\begin{array}{l}\text { The maintenance of tables helps to avoid their damages } \\
\text { which makes it possible for students' books to be kept } \\
\text { on it, thereby promoting effective learning and } \\
\text { performances. }\end{array}$ & 2.44 & 1.51 & Agreed \\
\hline 5 & $\begin{array}{l}\text { The maintenance of school desk helps students to take } \\
\text { notes } \\
\text { comfortably, thereby encouraging high academic } \\
\text { performance. }\end{array}$ & 2.62 & 2.15 & Agreed \\
\hline Gran & nd Mean & 2.83 & 0.956 & Agreed \\
\hline
\end{tabular}

Table 1 shows that maintenance of blackboard which helps the students to see clearly, thereby enhancing their academic performance, maintenance of wooden which helps the students to sit orderly, thereby motivating them to learn effectively, maintenance of tables which helps to avoid their damages which makes it possible for students' books to be kept on it, thereby promoting effective learning and performances, maintenance of school desk which helps students to take notes comfortably, thereby encouraging high academic performance are the extent school furniture affects students' academic performance in senior secondary schools as indicated in item 1, 2, 4, and 5 having the mean rating of 3.50, 2.61, 3.50 and 2.61 respectively. However, item 3 was not accepted by the majority of the respondents having the grand mean of 1.94 which is below the decision mean value of 2.50. This entails that they did not agree that maintenance of shelves helps in keeping books properly to avoid spoilage which makes the books handy for students to read, thereby facilitating students' learning outcome. The grand mean value of 2.83. shows that majority of the respondents agreed that the above are the extent school furniture is being maintained for effective academic performance of students. 
Research Question Two: To what extent does maintenance of school building affect students' academic performance in public secondary school in Bayelsa state?

Table 2: Mean ratings and standard deviation of the respondents on the extent maintenance of school building influences students' academic performance in public secondary school in Bayelsa state.

\begin{tabular}{|c|c|c|c|c|}
\hline $\mathrm{S} / \mathrm{N}$ & Description of Items & $\mathbf{X}$ & S. D Decision & \\
\hline 1 & $\begin{array}{l}\text { The maintenance of photocopying machines makes it } \\
\text { possible for students to photocopy good educational } \\
\text { materials for their private use, thereby enhancing } \\
\text { student's retention ability. }\end{array}$ & 2.10 & 1.09 & Agreed \\
\hline 2 & $\begin{array}{l}\text { The steady maintenance of library makes it possible } \\
\text { for reliable and } \\
\text { current books to be available for students to study } \\
\text { wide and research upon, which enables them to } \\
\text { perform high academically. }\end{array}$ & 3.18 & 1.01 & Agreed \\
\hline 3 & $\begin{array}{l}\text { The maintenance of library seats and table s helps the } \\
\text { students to seat } \\
\text { comfortably and read, thereby facilitating their } \\
\text { academic performances. }\end{array}$ & 3.50 & .62 & Agreed \\
\hline 4 & $\begin{array}{l}\text { The maintenance of computers helps in cataloguing } \\
\text { which improve the } \\
\text { convenience of students in reading and retrieval of } \\
\text { information for optimum performance. }\end{array}$ & 2.10 & 1.09 & Agreed \\
\hline 5 & $\begin{array}{l}\text { The maintenance of study carrels provides students } \\
\text { with space for their } \\
\text { study and research in order to achieve high academic } \\
\text { excellence. }\end{array}$ & 2.67 & 1.20 & Agreed \\
\hline \multicolumn{2}{|r|}{ Grand Mean } & 2.71 & 1.002 & Agreed \\
\hline
\end{tabular}

Table 2 shows that maintenance of laboratory buildings enhances students' participation in science practical thereby, the maintenance of ICT building enables students to take part in ICT classes effectively, maintenance of staffroom building makes teachers to sit tight in the staffroom while waiting for their different lesson periods for the students to easily locate them, maintenance of library building helps to prevent the books from spoilage, as such the students have enough reliable books to read, which leads to high intellectual ability in the students mental quotients of the students are the extent maintenance of school building affect students' academic performance in public secondary school in Bayelsa State as shown in the their mean values of $3.12,3.21,3.18$ and 3.50 on items $2,3,4,910$ respectively. But the majority of the respondents did agree that maintenance of classroom building helps the students to stay together and learn comfortably during teaching and learning process, thereby encouraging students' academic achievement as indicated on item 1 with the mean ratings of 1.94.

Research Question Three: To what extent does maintenance of school library facilities affect students' academic performance in public secondary schools in Bayelsa state? 
Table 3: Mean ratings and standard deviation of the respondents on the extent maintenance of school library facilities influences students' academic performance in public secondary schools in Bayelsa state.

\begin{tabular}{|c|c|c|c|c|}
\hline $\mathrm{S} / \mathrm{N}$ & Description of Items & $\mathbf{X}$ & S. D & Decision \\
\hline 1 & $\begin{array}{l}\text { The maintenance of photocopying machines makes it } \\
\text { possible for students to photocopy good educational } \\
\text { materials for their private use, thereby enhancing } \\
\text { student's retention ability. }\end{array}$ & 2.10 & 1.09 & Agreed \\
\hline 2 & $\begin{array}{l}\text { The steady maintenance of library makes it possible } \\
\text { for reliable and } \\
\text { current books to be available for students to study } \\
\text { wide and research upon, which enables them to } \\
\text { perform high academically. }\end{array}$ & 3.18 & 1.01 & Agreed \\
\hline 3 & $\begin{array}{l}\text { The maintenance of library seats and table s helps the } \\
\text { students to seat } \\
\text { comfortably and read, thereby facilitating their } \\
\text { academic performances. }\end{array}$ & 3.50 & .62 & Agreed \\
\hline 4 & $\begin{array}{l}\text { The maintenance of computers helps in cataloguing } \\
\text { which improve the convenience of students in reading } \\
\text { and retrieval of information for } \\
\text { optimum performance. }\end{array}$ & 2.10 & 1.09 & Agreed \\
\hline 5 & $\begin{array}{l}\text { The maintenance of study carrels provides students } \\
\text { with space for their } \\
\text { study and research in order to achieve high academic } \\
\text { excellence. }\end{array}$ & 2.67 & 1.20 & Agreed \\
\hline Gran & d Mean & 2.71 & 1.002 & Agreed \\
\hline
\end{tabular}

Table 3: The data show that maintenance of photocopying machine makes it possible for students to photocopy good educative materials for their private use, thereby enhancing students retention ability, steady maintenance of library makes it possible for reliable and current books to be available for students to study wide and research upon, which enables them to perform high academically, maintenance of library seats and table s helps the students to seat comfortably and read, thereby facilitating their academic performances, maintenance of computers helps in cataloguing which improve the convenience of students in reading and retrieval of information for optimum performance, maintenance of study carrels provides students with space for their study and research in order to achieve high academic excellence are the extent maintenance library facilities affects academic performance of students in public secondary schools in Rivers State.

\section{Test of Hypotheses}

Hypothesis One: There is no significant relationship between maintenance of school furniture and students 'academic performance in public secondary schools in Bayelsa state. 
Table 4: Pearson's Product Moment Correlation Analysis of significant relationship between maintenance of school furniture and students 'academic performance in public secondary schools in Bayelsa state.

\begin{tabular}{lllll}
\hline Variables & N & R & r-squared & Remarks School furniture \\
\hline Students' Performance & 283 & 0.43 & 0.18 & Positive Low Relationship Significance
\end{tabular}

From the result in table 4 , the sample size was $283, \mathrm{R}=0.43$ while $\mathrm{r}$-squared was 0.18 . the correlation coefficient of 0.43 shows that there is positive relationship between maintenance of school furniture and academic performance of students in public secondary schools in Rivers State

Hypothesis Two: There is no significant relationship between maintenance of school building and students' academic performance in public secondary schools in Bayelsa state.

Table 5: Pearson's Product Moment Correlation Analysis of significant relationship between maintenance of school building and students' academic performance in public secondary schools in Bayelsa state.

\begin{tabular}{lllllc}
\hline Variables & $\mathrm{N}$ & $\mathrm{R}$ & \multicolumn{2}{c}{ r-squared } & Remarks School building \\
Academic performance & 283 & 0.35 & 0.12 & Positive Low Relationship Significance \\
\hline
\end{tabular}

From the result in Table 5, the sample size was $283, \mathrm{R}=0.43$ while $\mathrm{r}-$ squared was 0.12 . The correlation coefficient of 0.35 shows that there is a positive low relationship between maintenance of a school building and students' academic performance in public secondary schools in Rivers State.

Hypothesis Three: There is no significant relationship between maintenance of school library facilities and students' academic performance in public secondary schools in Bayelsa State.

Table 6: Pearson's Product Moment Correlation Analysis of significant relationship between maintenance of school library facilities and students' academic performance in public secondary schools in Bayelsa state.

\begin{tabular}{lllll} 
Variables & N & R & \multicolumn{2}{c}{ r-squared $\quad$ Remarks School library } \\
Academic Performance & 283 & 0.45 & 0.20 & Positive Low Relationship Significance
\end{tabular}


From the result in table 6 , the sample size was $283, \mathrm{R}=0.45$ while $\mathrm{r}$-squared was 0.20 . The correlation coefficient value of 0.45 indicates that, there is a positive relationship between

maintenance of library facilities and students' academic performance in public secondary schools in Rivers State.

\section{SUMMARY OF FINDINGS}

1. The extent in which the school furniture is being maintained for students' academic performance in public secondary schools in Bayelsa state includes maintenance of blackboard which helps the students to see clearly, thereby enhancing their academic performance; maintenance of wooden which helps the students to sit orderly, thereby motivating them to learn effectively; maintenance of tables which helps to avoid their damages which makes it possible for students books to be kept on it, thereby promoting effective learning and performances; maintenance of school desk which helps students to take notes comfortably, thereby encouraging high academic performance. Also, there is a significant positive low relationship between maintenance of school furniture and students' academic performance in public secondary schools in Rivers State.

2. The extent maintenance of school building is maintained for students' academic performance in public secondary school in Bayelsa State includes maintenance of laboratory buildings which enhances students' participation in science practical thereby, the maintenance of ICT building enables students to take part in ICT classes effectively; maintenance of staffroom building makes teachers to sit tight in the staffroom while waiting for their different lesson periods for the students to easily locate them; maintenance of library building helps to prevent the books from spoilage, as such the students have enough reliable books to read, which leads to high intellectual ability in the students mental quotients of the students. There is a significant positive low relationship between maintenance of school building and students' academic performance in public secondary schools in Rivers State.

3. Extent school library facilities are being maintained for students' academic performance in public secondary schools in Bayelsa state includes maintenance of photocopying machine makes it possible for students to photocopy good educative materials for their private use, thereby enhancing students retention ability; steady maintenance of library makes it possible for reliable and current books to be available for students to study wide and research upon, which enables them to perform high academically; maintenance of library seats and table s helps the students to seat comfortably and read, thereby facilitating their academic performances; maintenance of computers helps in cataloguing which improve the convenience of students in reading and retrieval of information for optimum performance; maintenance of study carrels provides students with space for their study and research in order to achieve high academic excellence are the extent maintenance library facilities affects academic performance of students. There is a significant positive low relationship between maintenance of library facilities and students' academic performance in public secondary schools in Rivers State. 


\section{CONCLUSION}

This study has established the relationship between school plants maintenance and students' academic performances in public senior secondary schools in Bayelsa State. The study revealed that the maintenance of a school plant is very important to guarantee effective students' performance. Thus, variable school plants such as school building, classroom building, school conveniences, school environment, school library and laboratory showed positive relationships with students' academic performances in public secondary schools in Rivers State. This indicated the general performance of secondary school students in public secondary schools in Bayelsa State. Therefore, students' academic performance is a function of the school plant's maintenance. Hence, the provision and effective maintenance culture of school plants enhance students' academic performances in public secondary schools in Bayelsa State.

\section{RECOMMENDATIONS}

Based on the findings of this study, the researcher itemized the following recommendations.

- The government and schools board should often investigate the level of fitness and stability of school plants and embark on renovation and replacement of dilapidated and wornout facilities in order to promote students' academic performances.

- $\quad$ Principals should adopt an effective maintenance culture to avoid damage of school plants to avoid complete damage of school plants.

\section{REFERENCE}

Adesina, O. B. (2011). School plant planning as correlates of students' academic performance in Southwest Nigeria Secondary Schools. International Journal of Business Administration, 2(2), 41-47. http://org.doi:10.5430/ijba.v2n2p41

Ajayi, I. A. (1999). Issues in school management. Bola bay Publications.

Akomolafe, C. O., \& Adesua, V. O. (2016). The impact of physical facilities on students' level of motivation and academic performance in senior secondary schools in South West Nigeria. Journal of Education and Practice, 7(4), 38-42.

Akomolafe, C. O., \& Adesua, V. O. (2016). The Impact of physical facilities on students' level of motivation and academic performance in senior secondary schools in South West Nigeria. Journal of Education and Practice, 7(4), 38-42.

Amanchukwu, R., \& Ololube, N. P. (2015). Managing school plant for effective service delivery in public secondary schools in Rivers State of Nigeria. Human Resource Management Research, 5(4), 95-102. http://doi.org.10.5923/j.hrmr.20150504.02

Asiabaka, I. P. (2008). The need for effective facility management in schools in Nigeria. New York Science Journal, 1(2), 10-21.

Asiyai, R. I. (2012). Assessing school facilities in public secondary schools in Delta State, Nigeria. African research review. An International Multidisciplinary Journal, Ethiopia, 6(2), 192-205. 
Ekpoh, U. I. (2018). Teachers' satisfaction with physical working environment: imperative for effective service delivery. Journal of Education and Human Development, 7(1), 92-97.

Njoku, D.C. (2004). Relationship between organizational factors and administrative effectiveness of university academic managers in Imo and Rivers State of Nigeria. Unpublished M.Ed thesis, Faculty of Technical and Science Education, Rivers State University Press.

Nweneka, A.O. (2016). Assessment of availability and maintenance of school plant in secondary schools in Zaria education Zone, Kaduna State. Department of educational foundations and curriculum educational administration and planning section Aumadu Bello university zone.

Olaniyan, O.D and K.I. Anthony, 2013. Effect of inadequate school plant on academic performance of nigerian secondary school students. International Journal of Humanities and Management Sciences, 1(3): 198-200.

Oluchukwu, S. (2000). Challenges of educational planning in the $21^{\text {st }}$ century. Ben Ray.

Owhondah, S. N. Assessing the maintenance of e-learning facilities for quality university education in rivers state, Nigeria. International Multidisciplinary Academic Research Journal, 3(1), 8-23.

Usman, Y. D. (2016). Educational resources: an integral component for effective school administration in Nigeria. Research on Humanities and Social Sciences, 6(13), 27-37.

Wordu, H. and Nlerenchi, W.W (2018). School plant management for effective instructional delivery in public senior secondary schools in Port Harcourt metropolis. International Journal of Education And Evaluation, 4(8) 67-76.

Xaba, M. I. (2012). A qualitative analysis of facilities maintenance: a school governance function in South Africa. South African Journal of Education, 32(2), 215-226. 